\title{
QUEEN'S
UNIVERSITY
BELFAST
}

\section{Relationship between physical activity and bone mineral status in young adults: the Northern Ireland Young Hearts Project}

Neville, C., Murray, L., Boreham, C. A. G., Gallagher, A. M., Twisk, J., Robson, P. J., Savage, M., Kemper, H. C. G., Ralston, S. H., \& Davey Smith, G. (2002). Relationship between physical activity and bone mineral status in young adults: the Northern Ireland Young Hearts Project. Bone, 30(5), 792-798.

\section{Published in:}

Bone

Queen's University Belfast - Research Portal:

Link to publication record in Queen's University Belfast Research Portal

\section{General rights}

Copyright for the publications made accessible via the Queen's University Belfast Research Portal is retained by the author(s) and / or other copyright owners and it is a condition of accessing these publications that users recognise and abide by the legal requirements associated with these rights.

Take down policy

The Research Portal is Queen's institutional repository that provides access to Queen's research output. Every effort has been made to ensure that content in the Research Portal does not infringe any person's rights, or applicable UK laws. If you discover content in the Research Portal that you believe breaches copyright or violates any law, please contact openaccess@qub.ac.uk. 


\title{
Relationship Between Physical Activity and Bone Mineral Status in Young Adults: The Northern Ireland Young Hearts Project
}

\author{
C. E. NEVILLE,${ }^{1}$ L. J. MURRAY,${ }^{2}$ C. A. G. BOREHAM,${ }^{1}$ A. M. GALlaGHER,${ }^{3}$ J. TWISK,${ }^{4}$ \\ P. J. ROBSON ${ }^{3}$ J. M. SAVAGE ${ }^{5}$ H. C. G. KEMPER, ${ }^{4}$ S. H. RALSTON ${ }^{6}$ and G. DAVEY SMITH ${ }^{7}$
}

${ }^{1}$ School of Applied Medical Sciences and Sports Studies, University of Ulster, Jordanstown, Northern Ireland, ${ }^{2}$ Department of Epidemiology and Public Health, The Queen's University of Belfast, Belfast, Northern Ireland, ${ }^{3}$ Northern Ireland Centre for Diet and Health (NICHE), University of Ulster, Coleraine, Northern Ireland, ${ }^{4}$ Institute for Research in Extramural Medicine, Vrije Universiteit, Amsterdam, The Netherlands, ${ }^{5}$ Department of Child Health, The Queen's University of Belfast, Belfast, Northern Ireland, ${ }^{6}$ Department of Medicine and Therapeutics, University of Aberdeen, Aberdeen, Scotland and ${ }^{7}$ Department of Social Medicine, University of Bristol, Bristol, UK

Physical activity during the first three decades of life may increase peak bone mass and reduce future osteoporosis risk. The aim of this study was to determine the extent to which different components of physical activity may influence bone mineral status within a representative population sample of young men and women. Bone mineral density (BMD) and content (BMC) were determined at the lumbar spine and femoral neck in 242 men and 212 women, aged 20-25 years, by dual-energy $\mathrm{X}$-ray absorptiometry. Physical activity was assessed by a self-report questionnaire designed to measure the frequency and duration of physical activity and its components (i.e., work, non-sports leisure, sports-related activities, and peak strain sports activities). Potential confounding factors such as height, weight, diet, and smoking habits were also assessed. In multivariate linear regression models, sports activity and peak strain sports activity undertaken by men were strongly associated with both lumbar spine BMD ( $\beta=$ $0.35[0.21,0.49]$ and $\beta=0.31[0.17,0.44]$, respectively) and $\operatorname{BMC}(\beta=0.33[0.21,0.45]$ and $\beta=0.26[0.14,0.38]$, respectively) and femoral neck BMD $(\beta=0.35[0.21,0.48]$ and $\beta=0.27[0.14,0.40]$, respectively $)$ and $B M C(\beta=0.32$ $[0.19,0.44]$ and $\beta=0.29[0.17,0.41]$, respectively) (all $p<$ 0.01), but work and non-sports leisure activities were not. In women, there were no associations between bone measurements and any component of physical activity. In models involving all subjects the gender/sports activity, but not the gender/peak strain, interaction term was statistically significant. Sports activity explained $10.4 \%$ of the observed variance in lumbar spine BMD in men, but $<1 \%$ in women. These results demonstrate the importance of sports activities, especially those involving high peak strain, in determining peak bone status in young men. Failure to observe this association in women reflects their lower participation in such activities, but they may have the same capacity to benefit from these activities as men. Intervention studies are warranted to determine whether peak bone density in women can be improved by participating, during childhood and adolescence, in sports activities involving high peak strain. (Bone 30:792-798; 2002) (C) 2002 by Elsevier Science Inc. All rights reserved.
Key Words: Peak strain; Sports; Gender; Physical activity; Bone mineral density (BMD); Young adulthood.

\section{Introduction}

Osteoporosis-related fractures are a major public health problem. Demographic patterns and secular trends in osteoporosis look set to ensure that, globally, the magnitude of this problem will increase substantially over the next few decades. ${ }^{4}$ Although significant advances have been made in the treatment of osteoporosis, much attention is still focused on preventive strategies.

There is considerable evidence to suggest that the risk of osteoporosis and its sequelae may be reduced by maximizing the accrual of peak bone mass in the first few decades of life. ${ }^{16,20}$ Although it is recognized that bone mineral status is primarily under genetic influence, ${ }^{15,25}$ modifiable lifestyle factors,${ }^{26}$ of which physical activity may well be the most important, can have a major impact on bone development, maintenance, and strength. $5,6,8,18,28,32$

Recent evidence suggests that weight-bearing physical activity may confer greater benefits on bone status than non-weightbearing activity. ${ }^{8,30}$ In addition, activities involving considerable impact or strain have been shown to stimulate osteogenic responses. ${ }^{12,16,27}$ However, of the studies to date, many have been carried out with athletes ${ }^{11,18}$ and older age groups, ${ }^{12}$ or have used small sample sizes, ${ }^{2,7}$ and are not representative of young adult populations. Furthermore, many studies do not discriminate between different types of physical activity (e.g., work, leisure, sports, and peak strain activities) and do not account for intensity, frequency, and duration of physical activity in their analyses.

Consequently, the purpose of this study was to examine associations between measurements of bone mineral status and the different components of total physical activity in a large, representative sample of young adults.

Address for correspondence and reprints: Dr. Colin Boreham, School of Applied Medical Sciences and Sports Studies, University of Ulster, Jordanstown, Shore Road, Newtownabbey BT37 0QB, Northern Ireland. E-mail: ca.boreham@ulst.ac.uk 


\section{Materials and Methods}

\section{Study Population}

This study was conducted as part of an ongoing longitudinal study, The Young Hearts Project, which initially examined the prevalence of coronary risk factors in young people $(n=1015$; aged 12 years and 15 years) in Northern Ireland. The sampling procedures employed and the response rates obtained in the initial screening phase (YH1), which are described in detail elsewhere, ${ }^{23}$ resulted in a $2 \%$ representative sample of Northern Irish schoolchildren. All subjects in the original cohort were invited to participate in the third screening phase (YH3) between October 1997 and October 1999. Four hundred eighty-nine $(48.2 \%)$ subjects were examined, 250 men and 239 women, then aged between 20 and 25 years. Bone scans were performed on 242 men and 212 women. Ethical approval was obtained from the medical research ethical committee of The Queen's University of Belfast, and written informed consent was obtained from all participating subjects.

\section{Anthropometry and Other Measurements}

Measurements of height and weight were carried out on each subject. Standing height was measured to the nearest millimeter using a Harpenden portable stadiometer (Holtain, UK). Body weight was measured to the nearest $0.1 \mathrm{~kg}$ using an electronic balance $(200 \mathrm{~kg} \times 0.1 \mathrm{~kg}$; SECA, Alpha, Germany). For both measurements, subjects wore light indoor clothing and no shoes. Body mass index (BMI) was computed as weight $(\mathrm{kg}) / \mathrm{height}$ $\left(\mathrm{m}^{2}\right)$. Usual dietary habits were assessed using the diet history method, ${ }^{31}$ and energy and nutrient intakes were calculated using a computerized food analysis program (IUNAWISP, Tinuviel Software, Warrington, UK).

\section{Assessment of Frequency, Duration, and Type of Physical Activity}

Physical activity data were obtained using a modification of the Baecke questionnaire of habitual physical activity. ${ }^{21}$ This validated method ${ }^{19}$ was designed to quantify work activity, sports activity, and non-sports leisure activity. In brief, work activity was ascertained by the type of work and also the frequency of sitting, standing, walking, lifting heavy loads, physical tiredness, and whether the subject usually sweated. Questions regarding sports activity were designed to determine the frequency (months per year), duration (mean hours per week), and intensity (megajoules per hour) of up to four sporting activities. Subjects were also questioned about non-sports leisure time activity, including frequency of watching television, walking, cycling, and other exercise activities. Indices of work activity, sports activity, and non-sports leisure activity, based on a five-point Likert scale, were calculated. ${ }^{21}$ A total physical activity score was obtained from the sum of the three indices, giving a possible score for total physical activity ranging from 3 to 15 .

\section{Categorization of Activities by Peak Strain}

A peak strain score was assigned to each sports activity recorded on the self-report questionnaire. Peak strain scores were based on ground reaction forces of physical activities and were classified according to the method of Groothausen et al. ${ }^{8}$ This method assigns four levels of peak strain: vigorous activities involving jumping actions have a peak strain score of 3 ; activities that involve repetitive sprinting and turning have a peak strain score of 2; other weight-bearing activities have a peak score of 1 ; and all other activities have a peak strain score of 0 . By the method of Groothausen et al. ${ }^{8}$ peak scores of all recorded activities were either summed to give a total peak strain score or the highest peak score was selected. This method only accounted for activities undertaken during the previous 3 month period, however, and failed to discriminate among differences in the duration and frequency at which the peak strain activities were undertaken. For example, an individual who played squash for 1 hour/week obtained the same peak strain score as someone who played squash for 10 hour/week. In the present study, we constructed a total peak strain intensity score to incorporate the wide range of level of participation in reported physical activities. This took into account the frequency (months per year) and duration (mean hours per week) of individual physical activity over the previous 12 month period, thus providing a more detailed representation of peak strain associated with physical activity on an individual basis.

\section{Assessment of Bone Mineral Density}

Bone mineral density (BMD) and bone mineral content (BMC) of the lumbar spine region (L2-4) and femoral neck (hip) were measured by dual-energy X-ray absorptiometry, using the Lunar Expert-XL bone densitometer (Lunar Corp., Madison, WI). This densitometer has a precision of $1.0 \%$ in vivo and $0.5 \%$ in vitro (Lunar). Prior to each scan, the densitometer was calibrated by a qualified radiographer, according to the manufacturer's recommendations. The results from the scan were expressed as BMC in grams of calcium hydroxyapatite, and BMD in grams of calcium hydroxyapatite $/ \mathrm{cm}^{2}$. Separate scans were taken of the L2-4 lumbar vertebrae and the femoral neck. Scans of the women were undertaken within 10 days of commencement of their last menstrual period.

\section{Statistical Analyses}

All statistical analyses were performed with SPSS for Windows, version 10 (SPSS, Inc.). Initially, multivariate linear regression models were constructed that included data for both men and women in order to assess the extent to which gender differences in BMD and BMC could be attributed to differences in sports activity and peak strain activity. These models were developed by inclusion of the lifestyle variables and gender/lifestyle variable interaction terms. Age was included in all models as both age group and the variation within each age group. As several of the gender/lifestyle interaction terms achieved statistical significance, separate models were constructed for each gender.

Gender-specific models were constructed with BMD and $\mathrm{BMC}$ at the femoral hip and lumbar spine as the dependent variables. Both height and weight were included in these models as they are well-recognized as being important for measurement and prediction of BMD. Because sports activity and peak strain activity were highly correlated (correlation coefficient 0.69), they were not entered into the same multivariate models. Instead, separate gender-specific models, which included either sports, non-sports leisure, and work activity (the physical activity model), or peak strain activity (the peak strain activity model), were constructed. Dietary variables that have previously been shown to be related to bone density, smoking habit, and alcohol consumption were also included in these models.

Results from the gender-specific models analyses were expressed as standardized regression coefficients. The standardized coefficient represents the predicted difference in the dependent variable corresponding to a difference of one standard deviation of the independent variable.

Finally, the relative importance of sets of explanatory vari- 
Table 1. The Young Hearts Study population: Physical characteristics, bone mineral measurements, physical activity scores, and nutrient intakes

\begin{tabular}{|c|c|c|}
\hline & $\begin{array}{c}\text { Men }(\mathrm{n}=250) \\
\text { mean }(\mathrm{SD})\end{array}$ & $\begin{array}{c}\text { Women }(\mathrm{n}=239) \\
\text { mean }(\mathrm{SD})\end{array}$ \\
\hline Age (years) & $22.4(1.60)$ & $22.8(1.66)$ \\
\hline Height (m) & $1.78(0.07)$ & $1.64(0.06)$ \\
\hline Weight $(\mathrm{kg})$ & $75.3(11.5)$ & $64.6(12.0)$ \\
\hline Body mass index $\left(\mathrm{kg} / \mathrm{m}^{2}\right)$ & $23.8(3.1)$ & $23.9(4.3)$ \\
\hline Bone mineral density of lumbar spine $\left(\mathrm{g} / \mathrm{cm}^{2}\right)^{\mathrm{a}}$ & $1.28(0.14)$ & $1.19(0.12)$ \\
\hline Bone mineral content of lumber spine $(\mathrm{g})^{\mathrm{a}}$ & $62.71(10.5)$ & $51.40(8.77)$ \\
\hline Bone mineral density of femoral neck $\left(\mathrm{g} / \mathrm{cm}^{2}\right)^{a}$ & $1.14(0.17)$ & $1.05(0.15)$ \\
\hline Bone mineral content of femoral neck $(\mathrm{g})^{\mathrm{a}}$ & $6.19(0.95)$ & $4.85(0.72)$ \\
\hline Total physical activity (score) $)^{\mathrm{b}-\mathrm{d}}$ & $7.96(1.40)$ & $7.41(1.20)$ \\
\hline Work activity (score) $)^{\mathrm{b}, \mathrm{d}}$ & $2.83(0.65)$ & $2.58(0.53)$ \\
\hline Non-sports leisure activity $(\text { score })^{\mathrm{b}, \mathrm{d}}$ & $2.38(0.68)$ & $2.40(0.57)$ \\
\hline Sports activity (score) $)^{\mathrm{b}, \mathrm{d}}$ & $2.75(0.80)$ & $2.43(0.64)$ \\
\hline Total peak strain intensity $(\text { score })^{\mathrm{b}}$ & $0.90(1.16)$ & $0.29(0.56)$ \\
\hline
\end{tabular}

${ }^{\mathrm{a} M e n,} \mathrm{n}=242 ;$ women, $\mathrm{n}=212$.

${ }^{\mathrm{b}}$ Men, $\mathrm{n}=248 ;$ women, $\mathrm{n}=237$.

${ }^{\mathrm{c}}$ Total physical activity $=$ work activity + non-sports leisure activity + sports activity.

${ }^{\mathrm{d}}$ Possible range of physical activity scores: total, $3-15$; work, 1-5; non-leisure sports, $1-5$; sports, 1-5.

ables included in the gender-specific models was examined by decomposing the coefficient of determination $R^{2}$ using the hierarchical partitioning method. ${ }^{3}$ In this technique, explanatory variables were grouped into three blocks. Block 1 included age, height, weight, smoking, alcohol intake, non-sports leisure activity, and work activity; block 2 included sports activity (or peak strain activity) only; and block 3 included the dietary variables of total energy, calcium, protein, phosphorus, total fat, and vitamin $\mathrm{D}$.

\section{Results}

Of the subjects who participated in the present study, $51.1 \%(\mathrm{n}=$ $250)$ were men and $48.9 \%(n=239)$ were women. Response rates were higher in nonmanual social classes compared with manual social classes: Of the subjects who attended $\mathrm{YH} 3,58.6 \%$ $(\mathrm{n}=228)$ were from nonmanual social classes defined at YH1 and $43.8 \%(n=205)$ were from manual social classes $(\chi=18.6$, $d f 1, p<0.01)$. Nonattending men, but not women, were heavier and fatter and had a higher saturated fat intake at YH1 than attending men. There were no differences between responders and nonresponders, of either gender, in physical activity scores measured during YH1.

Table 1 summarizes the physical characteristics of the study population and presents summary data on the distribution of bone mineral measurements. Table 2 presents the results of the multivariate linear regression analyses that included all subjects. Statistically, all bone measurements were seen to differ between the genders with women having lower values than men. These differences decreased in magnitude by up to 33\% (lumbar spine BMD), but remained statistically significant following adjustment for sports activity or peak strain activity with the largest changes seen for BMD at the lumbar spine. Further adjustment for height and weight substantially attenuated the remaining gender differences.

Table 3 presents the results of the multiple regression analyses using the total physical activity model. Variables entered into the model included age group (older vs. younger), age variation within the group, height, weight, smoking, alcohol intake, the components of total physical activity (i.e., work, non-sports leisure, and sports), and dietary variables (i.e., energy, calcium, protein, phosphorus, total fat, and vitamin D). Dietary variables are not included in the table. In men, age showed a significant negative relationship with femoral neck BMD and BMC. Height was significantly positively related with lumbar spine BMC in both men and women, and also with femoral neck BMC in women. Weight had a significant positive relationship with all bone mineral measurements in both genders. In men, but

Table 2. Unadjusted and adjusted mean differences in bone indices between genders

\begin{tabular}{lccc}
\hline Bone site & Unadjusted difference & $\begin{array}{c}\text { Adjustment for sports } \\
\text { activity only }\end{array}$ & $\begin{array}{c}\text { Further adjustment for height } \\
\text { and weight }\end{array}$ \\
\hline Lumbar spine BMD & $-0.06(-0.08,-0.04)$ & $-0.05(-0.07,-0.02)$ & $-0.02(-0.05,0.01)$ \\
Lumbar spine BMC & $-11.4(-13.3,-9.66)$ & $-10.5(-12.3,-8.69)$ & $-1.39(-3.50,0.73)$ \\
Femoral neck BMD & $-0.09(-0.12,-0.06)$ & $-0.08(-0.11,-0.05)$ & $-0.04(-0.08,0)$ \\
Femoral neck BMC & $-1.35(-1.50,-1.19)$ & $-1.24(-1.40,-1.08)$ & $-0.66(-0.85,-0.47)$ \\
& & Adjustment for peak & \\
Lumbar spine BMD & $-0.06(-0.08,-0.04)$ & $-0.04(-0.07,-0.02)$ & $-0.01(-0.04,0.03)$ \\
Lumbar spine BMC & $-11.4(-13.3,-9.66)$ & $-10.2(-12.1,-8.41)$ & $-0.70(-2.84,1.44)$ \\
Femoral neck BMD & $-0.09(-0.12,-0.06)$ & $-0.07(-0.10,-0.04)$ & $-0.03(-0.07,0.01)$ \\
Femoral neck BMC & $-1.35(-1.50,-1.19)$ & $-1.21(-1.38,-1.05)$ & $-0.59(-0.78,-0.40)$ \\
\hline
\end{tabular}

Figures shown are unstandardized regression coefficients (95\% confidence intervals).

KEY: BMD, bone mineral density $\left(\mathrm{g} / \mathrm{cm}^{2}\right)$; BMC, bone mineral content $(\mathrm{g})$. 
Table 3. Multiple regression analysis for the relationships between physical activity, lifestyle parameters, and bone measurements in men and women during young adulthood

\begin{tabular}{|c|c|c|c|c|c|}
\hline \multirow[b]{2}{*}{ Variable } & & \multicolumn{4}{|c|}{ Bone measurement } \\
\hline & & Lumbar spine BMD & Lumbar spine BMC & Femoral neck BMD & Femoral neck BMC \\
\hline \multirow{2}{*}{$\begin{array}{l}\text { Age group (older vs. } \\
\text { younger, years) }\end{array}$} & Men & $-0.09(-0.21,0.04)$ & $-0.05(-0.16,0.07)$ & $-0.17(-0.30,-0.05)^{\mathrm{b}}$ & $-0.16(-0.27,-0.04)^{\mathrm{b}}$ \\
\hline & Women & $0.06(-0.07,0.18)$ & $0.05(-0.06,0.16)$ & $-0.08(-0.21,0.05)$ & $-0.08(-0.20,0.03)$ \\
\hline \multirow[t]{2}{*}{ Height (m) } & Men & $-0.08(-0.23,0.07)$ & $0.33(0.20,0.46)^{\mathrm{b}}$ & $-0.05(-0.20,0.10)$ & $0.13(0,0.26)$ \\
\hline & Women & $0.04(-0.10,0.17)$ & $0.37(0.25,0.49)^{\mathrm{b}}$ & $0.08(-0.07,0.22)$ & $0.22(0.10,0.35)^{\mathrm{b}}$ \\
\hline \multirow[t]{2}{*}{ Weight (kg) } & Men & $0.25(0.10,0.40)^{\mathrm{b}}$ & $0.24(0.11,0.37)^{\mathrm{b}}$ & $0.25(0.11,0.40)^{\mathrm{b}}$ & $0.35(0.22,0.48)^{\mathrm{b}}$ \\
\hline & Women & $0.44(0.31,0.58)^{\mathrm{b}}$ & $0.42(0.30,0.53)^{\mathrm{b}}$ & $0.35(0.21,0.48)^{\mathrm{b}}$ & $0.48(0.36,0.60)^{\mathrm{b}}$ \\
\hline \multirow[t]{2}{*}{ Work activity (score) } & Men & $-0.03(-0.16,0.10)$ & $-0.04(-0.16,0.07)$ & $0.01(-0.13,0.12)$ & $-0.06(-0.17,0.06)$ \\
\hline & Women & $-0.07(-0.20,0.05)$ & $0.02(-0.09,0.13)$ & $-0.08(-0.20,0.05)$ & $-0.06(-0.17,0.06)$ \\
\hline \multirow{2}{*}{$\begin{array}{c}\text { Non-sports leisure } \\
\text { activity (score) }\end{array}$} & Men & $-0.06(-0.19,0.07)$ & $-0.12(-0.30,0)$ & $-0.13(-0.26,0)$ & $-0.07(-0.18,0.05)$ \\
\hline & Women & $0.01(-0.12,0.14)$ & $0.01(-0.10,0.13)$ & $0.01(-0.13,0.15)$ & $0.02(-0.10,0.14)$ \\
\hline \multirow[t]{2}{*}{ Sports activity (score) } & Men & $0.35(0.21,0.49)^{\mathrm{b}}$ & $0.33(0.21,0.45)^{\mathrm{b}}$ & $0.35(0.21,0.48)^{\mathrm{b}}$ & $0.32(0.19,0.44)^{\mathrm{b}}$ \\
\hline & Women & $0.05(-0.09,0.18)$ & $-0.01(-0.12,0.11)$ & $0.03(-0.11,0.17)$ & $0.06(-0.06,0.18)$ \\
\hline \multirow{2}{*}{$\begin{array}{l}\text { Smoking (current vs. } \\
\text { never or former) }\end{array}$} & Men & $0.08(-0.05,0.21)$ & $0.03(-0.09,0.15)$ & $-0.02(-0.15,0.11)$ & $-0.01(-0.12,0.11)$ \\
\hline & Women & $-0.08(-0.21,0.06)$ & $-0.04(-0.15,0.07)$ & $-0.05(-0.19,0.08)$ & $-0.01(-0.13,0.10)$ \\
\hline \multirow{2}{*}{ Alcohol (g) } & Men & $0.05(-0.13,0.23)$ & $0.04(-0.12,0.20)$ & $0.19(0.01,0.37)^{\mathrm{a}}$ & $0.16(0,0.33)^{\mathrm{a}}$ \\
\hline & Women & $-0.12(-0.27,0.03)$ & $-0.13(-0.26,0)^{\mathrm{a}}$ & $-0.05(-0.20,0.09)$ & $-0.02(-0.15,0.11)$ \\
\hline
\end{tabular}

Figures shown are standardized regression coefficients (95\% confidence intervals).

Displayed relationships were also adjusted for age variation within the group, and the following dietary variables: total energy, calcium, protein, phosphorus, total fat, and vitamin D.

$\mathrm{KEY}$ : BMD, bone mineral density $\left(\mathrm{g} / \mathrm{cm}^{2}\right)$; BMC, bone mineral content $(\mathrm{g})$.

${ }^{\mathrm{a}} p<0.05 ;{ }^{\mathrm{b}} \mathrm{p}<0.01$.

not women, sports activity was strongly positively associated with both lumbar spine and femoral neck BMD and BMC. Work activity did not show any independent relationship with bone mineral measurements in either gender. In men, the relationships between non-sports leisure activity and bone mineral measurements approached statistical significance and all were negative. Of the dietary variables, vitamin $\mathrm{D}$ was an independent predictor of femoral neck BMD $(\beta=0.22, p<0.01)$ and BMC $(\beta=0.17$, $p=0.01)$, in women only. Alcohol intake reported by women had a significant negative relationship with lumbar spine BMC, with the opposite effect being seen in men for femoral neck BMC and BMD.
In the peak strain activity models (Table 4), peak strain activity was significantly positively associated with BMD and $\mathrm{BMC}$ at both the lumbar spine and femoral neck, but only in men. The regression coefficients of other variables included in the model were little changed from the physical activity model.

The outcome of the hierarchical partitioning analysis of the sports activity models is shown in Table 5. In men, the full models explained $20.8 \%, 36.2 \%, 24.5 \%$, and $36.7 \%$ of the observed variance in lumbar spine BMD and BMC and femoral neck BMD and BMC, respectively. With the exception of femoral neck BMD the models for women explained slightly more of the variance in these measurements $(25.6 \%, 44.3 \%, 23.0 \%$, and

Table 4. Multiple regression analysis for the relationships between peak strain activity, lifestyle parameters, and bone measurements in men during young adulthood

\begin{tabular}{|c|c|c|c|c|c|}
\hline \multirow[b]{2}{*}{ Variable } & & \multicolumn{4}{|c|}{ Bone measurement } \\
\hline & & Lumbar spine BMD & Lumbar spine BMC & Femoral neck BMD & Femoral neck BMC \\
\hline \multirow{2}{*}{$\begin{array}{l}\text { Age group (older vs. } \\
\text { younger, years) }\end{array}$} & Men & $-0.09(-0.21,0.04)$ & $-0.05(-0.16,0.07)$ & $-0.18(-0.30,-0.05)^{\mathrm{b}}$ & $-0.16(-0.27,-0.04)^{b}$ \\
\hline & Women & $0.05(-0.08,0.17)$ & $0.05(-0.06,0.16)$ & $-0.08(-0.21,0.04)$ & $-0.09(-0.20,0.03)$ \\
\hline \multirow[t]{2}{*}{ Height (m) } & Men & $-0.08(-0.22,0.07)$ & $0.32(0.19,0.45)^{\mathrm{b}}$ & $-0.06(-0.21,0.09)$ & $0.13(0,0.26)^{\mathrm{a}}$ \\
\hline & Women & $0.04(-0.10,0.21)$ & $0.36(0.24,0.48)^{\mathrm{b}}$ & $0.08(-0.06,0.22)$ & $0.23(0.11,0.35)^{\mathrm{b}}$ \\
\hline \multirow[t]{2}{*}{ Weight (kg) } & Men & $0.29(0.14,0.43)^{\mathrm{b}}$ & $0.28(0.15,0.41)^{\mathrm{b}}$ & $0.30(0.15,0.45)^{\mathrm{b}}$ & $0.39(0.25,0.52)^{\mathrm{b}}$ \\
\hline & Women & $0.44(0.31,0.58)^{\mathrm{b}}$ & $0.43(0.31,0.54)^{\mathrm{b}}$ & $0.34(0.20,0.48)^{\mathrm{b}}$ & $0.48(0.36,0.60)^{\mathrm{b}}$ \\
\hline \multirow[t]{2}{*}{ Peak strain intensity (score) } & Men & $0.31(0.17,0.44)^{\mathrm{b}}$ & $0.26(0.14,0.38)^{\mathrm{b}}$ & $0.27(0.14,0.40)^{\mathrm{b}}$ & $0.29(0.17,0.41)^{\mathrm{b}}$ \\
\hline & Women & $0.05(-0.08,0.18)$ & $0.04(-0.07,0.15)$ & $0.00(-0.13,0.13)$ & $0.03(-0.08,0.14)$ \\
\hline \multirow{2}{*}{$\begin{array}{l}\text { Smoking (current vs. never } \\
\text { or former) }\end{array}$} & Men & $0.07(-0.06,0.20)$ & $0.01(-0.11,0.13)$ & $-0.04(-0.10,0.03)$ & $-0.02(-0.14,0.10)$ \\
\hline & Women & $-0.08(-0.21,0.05)$ & $-0.03(-0.14,0.08)$ & $-0.06(-0.20,0.07)$ & $-0.02(-0.14,0.10)$ \\
\hline \multirow[t]{2}{*}{ Alcohol (g) } & Men & $0.04(-0.14,0.22)$ & $0.04(-0.13,0.20)$ & $0.18(0,0.36)$ & $0.16(0,0.32)$ \\
\hline & Women & $-0.11(-0.26,0.03)$ & $-0.13(-0.26,-0.01)^{\mathrm{a}}$ & $-0.05(-0.20,0.11)$ & $-0.02(-0.15,0.12)$ \\
\hline
\end{tabular}

Figures shown are standardized regression coefficients (95\% confidence intervals).

Displayed relationships were also adjusted for age variation within the group and the following dietary variables: total energy, calcium, protein, phosphorus, total fat, and vitamin D.

KEY: BMD, bone mineral density $\left(\mathrm{g} / \mathrm{cm}^{2}\right)$; BMC, bone mineral content $(\mathrm{g})$.

a $p<0.05$

${ }^{\mathrm{b}} p<0.01$. 
Table 5. Variance in bone mineral density measurements explained by physical activity and dietary variables

\begin{tabular}{|c|c|c|c|c|}
\hline Sports activity model & $\begin{array}{l}\text { Total variance } \\
\text { explained by } \\
\text { the model }(\%)\end{array}$ & $\begin{array}{c}\text { Variance } \\
\text { explained by } \\
\text { block } 1^{\mathrm{a}}(\%)\end{array}$ & $\begin{array}{c}\text { Variance } \\
\text { explained by } \\
\text { sports activity }(\%)\end{array}$ & $\begin{array}{c}\text { Variance explained } \\
\text { by dietary variables } \\
(\%)\end{array}$ \\
\hline \multicolumn{5}{|l|}{ Men } \\
\hline Lumbar spine BMD & 20.8 & 7.0 & 10.4 & 3.3 \\
\hline Lumbar spine BMC & 36.2 & 25.4 & 8.7 & 2.0 \\
\hline Femoral neck BMD & 24.5 & 13.0 & 9.5 & 2.1 \\
\hline Femoral neck BMC & 36.7 & 24.2 & 9.5 & 3.0 \\
\hline \multicolumn{5}{|l|}{ Women } \\
\hline Lumbar spine BMD & 25.6 & 23.6 & 0.6 & 1.4 \\
\hline Lumbar spine BMC & 44.3 & 43.0 & 0.5 & 0.8 \\
\hline Femoral neck BMD & 23.0 & 16.6 & 0.9 & 5.5 \\
\hline Femoral neck BMC & 39.4 & 36.1 & 0.9 & 2.4 \\
\hline
\end{tabular}

KEY: BMD, bone mineral density $\left(\mathrm{g} / \mathrm{cm}^{2}\right)$; BMC, bone mineral content $(\mathrm{g})$.

${ }^{a}$ Variables in block 1 are age, height, weight, smoking, alcohol intake, non-sports leisure activity, and work activity.

${ }^{b}$ Dietary variables include total energy, calcium, protein, phosphorus, total fat, and vitamin D.

$39.4 \%$, respectively). The proportion of variance explained by sports activity in the models for men was more than ten times higher than that explained in the corresponding models for women and, in the lumbar spine BMD model in men, sports activity contributed half of the total variance explained. In all models for men, sports activity contributed substantially more to the explained variance than did the dietary variables; in women, however, the pattern was reversed. With the exception of femoral neck BMD, the variables in block 1 accounted for $>90 \%$ of the variance explained in the models for women, with height and weight contributing most to the effect of the block. Hierarchical partitioning of the peak strain models provided very similar results (data not shown).

\section{Discussion}

This study differs from previous reports investigating relationships between physical activity and bone measurements in that it examines a large number of normal young adults. It also concentrates on the contribution that the various components of physical activity may make to peak bone mass, with the intention of identifying those aspects of physical activity that could be promoted in order to achieve maximal BMD in early adulthood. The study encountered some response bias in that subjects from lower social classes (and fatter and heavier men) did not participate in the third phase of the study (in which bone density was measured) to the same extent as their counterparts from the higher classes. However, there were no differences between responders and nonresponders in reported activity patterns, which is the major focus of this report, when screened in the first phase of the study (aged 12 or 15 years).

There has been some debate in the literature regarding the age at which peak bone density is normally achieved. Early studies have suggested that this may not occur until the late third or fourth decade of life, ${ }^{13,22}$ but more recent work indicates that most adults have achieved peak bone mass by their early twenties. ${ }^{10,29}$ We found a significant negative association between age and bone mineral measurements of the femoral neck in men, suggesting that some subjects were already beginning to lose bone at this site. This finding accords well with Bonjour et al. ${ }^{1}$ who found that femoral neck BMD at age 17-18 years was $105 \%$ and $107 \%$ of the mean values recorded in 20-35-year-old women and men.

The reduction in the gender difference in bone measurements on adjusting for sports or peak strain activity seen in this study
(Table 2) gave an estimate of the proportion of the gender difference in these measurements that may be due to peak strain or sports activity. It is clear that the gender differences in bone measurements were due in large part to differences in body size (height and weight), but peak strain activity accounted for up to one third of the gender difference in lumbar spine BMD.

Physical activity is a complex behavior, and few studies have examined the role of activities other than sports-related physical activity in determining peak bone status. In the present study, only sports-related activity undertaken by men was associated with bone measurements in early adulthood. Work activity had no effect whereas non-sports leisure activity was negatively related to bone mineral measurements, indicating that involvement in these activities occurs at the expense of playing sport. These findings suggest that the occupation and recreation of many individuals involve insufficient mechanical strain to affect bone density. It is unlikely that the increasingly sedentary nature of occupations, which has become a feature of developed nations in recent decades, will be reversed. If anything, the trend is likely to accelerate. Therefore, sports-related activity may provide the only realistic means of improving peak BMD on both an individual and population basis. However, the failure to observe a relationship between sports activity and bone measurements in women, together with the fact that the gender/peak strain interaction term reached statistical significance (in the regression models that included all subjects), could be interpreted as indicating that women may have less capacity than men to benefit (in terms of peak bone mass) from sports-related activities. However, the explanation may lie in the nature of the sports activity undertaken by women.

Although little work has been carried out on population-based samples, ${ }^{8,26,32}$ high strain certainly appears to be a powerful osteogenic stimulus. ${ }^{16}$ Some sports, for example those involving high-intensity weight-bearing exercise, or high peak strains, appear to provide better opportunities for maximizing bone than others. ${ }^{5,11,27}$ However, previous reports have been constrained by routinely used methods for estimating peak strains. In the present study, we have been able to account for both the frequency with which subjects undertook peak strain activities, and the usual length of time spent at the activity. Using this modification we demonstrated, within a population-based sample, a positive association between high peak strain activity and BMD and BMC at important weight-bearing sites in early adulthood. However, it is important to note that this effect was apparent only in men. It has been suggested that the physiological effect of 
weight-bearing and non-weight-bearing activity on bone may differ between genders ${ }^{17}$ or that, after puberty, the effect of physical activity on bone status wanes in females, but not in males. ${ }^{9}$ However, the lack of statistical significance for the gender/peak strain activity in regression models, involving all subjects, does not support a difference between the genders in the effect of high peak strain activity on bone density, although the observed relationship was not as strong in women as it was in men. This suggests that our failure to observe a relationship between peak strain activity and bone density in young women is not because they do not have the capacity to benefit from this type of sports activity, but that they play sports involving high peak strain too infrequently to increase their bone density. The apparent gender difference in the relationship between participation in sports activities and peak bone mass probably also results from gender differences in the type of sport played.

The profile of sports undertaken by the subjects appears to support this interpretation of our data. Although fewer women than men ( $26.4 \%$ vs. $38.4 \%)$ participated in any sport, the most striking difference between the genders was in the type of sport played. The most common sport undertaken by $45.2 \%$ of men was football (soccer, gaelic, or rugby), which involves high peak strain, followed by walking $(6.5 \%)$ and swimming (5.4\%), whereas in women the most frequently reported sport was walking $(32.2 \%)$, which has a low peak strain score, followed by aerobics and gym workouts $(15.8 \%)$, the peak strain content of which may be variable.

It has generally been accepted that maximizing peak bone mass in early adulthood is likely to stave off the onset of osteoporosis and reduce future occurrence of osteoporosis-related fractures. ${ }^{16}$ However, a recently published study appears to cast doubt on this belief. ${ }^{14}$ This investigation of former and current soccer players and controls appeared to demonstrate that former soccer players lost bone at a greater rate than controls, but the study was underpowered ${ }^{24}$ and incident fracture rates were, in fact, $43 \%$ lower in former soccer players than in controls, indicating that maximizing peak bone mass in early adulthood may well protect against future fracture risk. At least for the time being, osteoporosis prevention strategies should continue to include approaches intended to maximize peak bone mass in early adulthood.

The present study demonstrates that sports activity in early adulthood, especially sports involving high peak strain activity, is strongly associated with peak bone mass in men. This relationship was not exhibited in young women, mostly likely because they did not participate in this type of activity on a sufficiently frequent basis. Our findings require replication in other populations and, if confirmed, intervention studies should be considered to determine whether promoting sports involving high peak strain (e.g., team sports) among girls and young women would result in improvements in peak bone density.

Acknowledgments: The authors thank all of the study subjects for their participation. We also thank Dr. Malcolm Crone and the Bone Densitometry Unit of Greenpark Healthcare Trust for their support, and the research nurses, Brenda Dolan and Katharine Walton, for assistance in the fieldwork. This research was supported by the Wellcome Trust and the British Heart Foundation.

\section{References}

1. Bonjour, J. P., Theinz, G., Buchs, B., Slosman, D., and Rizzoli, R. Critical years and stages of puberty for spinal and femoral bone mass accumulation during adolescence. J Clin Endocrinol Metab 73:555-563; 1991.

2. Brahm, H., Mallmin, H., Michaelsson, K., Strom, H., and Ljunghall, S.
Relationships between bone mass measurements and lifetime physical activity in a Swedish population. Calcif Tissue Int 62:400-412; 1998.

3. Chevan, A. and Sutherland, M. Hierarchical partitioning. Am Stat 45:90-96; 1991.

4. Cooper, C. Epidemiology and public health impact of osteoporosis. Bailliere's Clin Rheumatol 7:459-477; 1993.

5. Emslander, H. C., Sinaki, M., Muhs, J. M., Chao, E. Y. S., Wahner, H. W., and Bryant, S. C., et al. Bone mass and muscle strength in female college athletes. Mayo Clin Proc 73:1151-1160; 1998

6. Fehily, A. M., Coles, R. J., Evans, W. D., and Elwood, P. C. Factors affecting bone density in young adults. Am J Clin Nutr 56:579-586; 1992.

7. Grimston, S. K., Willows, N. D., and Hanley, D. A. Mechanical loading regime and its relationship to BMD in children. Med Sci Sports Exerc 25:1203-1210; 1993.

8. Groothausen, J., Siemer, H., Kemper, H. C. G., Twisk, J., and Welten, D. C. Influence of peak strain on lumbar bone mineral density: An analysis of 15 year physical activity in young males and females. Pediatr Exerc Sci 9:159-173; 1997.

9. Gunnes, M. and Lehmann, E. H. Physical activity and dietary constituents as predictors of forearm cortical and trabecular bone gain in healthy children and adolescents: A prospective study. Acta Paediatr 85:19-25; 1996.

10. Haapasalo, H., Kannus, P., Sievanen, H., Pasenen, M., Uusi-Rasi, K., and Heinonen, A., et al. Development of mass, density and estimated mechanical characteristics of bones in Caucasian females. J Bone Miner Res 11:1751$1760 ; 1996$.

11. Heinonen, A., Oja, P., Kannus, P., Sievanen, H., Manttari, A., and Vuori, I. Bone mineral density of females athletes in different sports. Bone Miner 23:1-14; 1993.

12. Heinonen, A., Oja, P., Sievanen, H., Pasanen, M., and Vuori, I. Effect of two training regimens on bone mineral density in healthy perimenopausal women: A randomized controlled trial. J Bone Miner Res 13:1483-1490; 1997.

13. Johnston, C. C. and Slemenda, C. W. Determinants of peak bone mass. Osteopor Int XX(Suppl. 3):54-55; 1993.

14. Karlsson, M. K., Linden, C., Karlsson, C., Johnell, O., Obrant, K., and Seeman, E. Exercise during growth and bone mineral density and fractures in old age. Lancet 355:469-470; 2000.

15. Kelly, P. J., Eisman, J. A., and Sambrook, P. N. Interaction of genetic and environmental influences on peak bone density. Osteopor Int 1:56-60; 1991

16. Lanyon, L. E. Taking the strain: Bones, exercise and oestrogen. Wellcome Trust Rev 8:18-21; 1999.

17. Matkin, C. C., Bachrach, L., Wang, M. C., and Kelsey, J. Two measures of physical activity as predictors of bone mass in a young cohort. Clin J Sports Med 8:201-208; 1998.

18. McCulloch, R. G., Bailey, D. A., Whalen, R. L., Houston, S. C., Faulkner, R. A., and Craven, B. R. Bone density and bone mineral content of adolescent soccer athletes and competitive swimmers. Pediatr Exerc Sci 4:319-330; 1992.

19. Montoye, H. J., Kemper, H. C. G., Saris, W. H. M., and Washburn, R. A Measuring Physical Activity and Energy Expenditure. Champaign, IL: Human Kinetics 1996; 50-51.

20. Parfitt, A. M. The two faces of growth: Benefits and risks to bone integrity Osteopor Int 4:382-398; 1994.

21. Pereira, M. A., Fitzgerald, S. J., Gregg, E. W., Joswiak, M. L., Ryan, W. J., and Suminski, R. R., et al. Baecke questionnaire of habitual activity. A collection of physical activity questionnaires for health-related research. Med Sci Sports Exerc 29:15-18; 1997.

22. Recker, R. R., Davies, M. K., Hinders, S. M., Heaney, R. P., Stegman, M. R., and Kimmel, D. B. Bone gain in young adult women. JAMA 268:2403-2408; 1992.

23. Robson, P. J., Gallagher, A. M., Livingstone, M. B. E., Cran, G. W., Strain J. J., Savage, J. M., and Boreham, C. A. G. Tracking of nutrient intakes in adolescence: The experiences of the Young Hearts Project, Northern Ireland. Br J Nutr 84:541-548; 2000.

24. Sievanan, H., McKay, H., Heinonen, A., Bailey, D., and Khan, K. The Achilles heel of exercise. Lancet 355:1909; 2000.

25. Slemenda, C. W., Christian, J. C., Williams, C. J., Norton, J. A., and Johnston, C. C., Jr. Genetic determinants of bone mass in adult women: A reevaluation of the twin model and the potential importance of gene interaction on heritability estimates. J Bone Miner Res 6:561-567; 1991.

26. Slemenda, C. W., Miller, J. Z., Hui, S. L., Reister, T. K., and Johnston, C. C. Role of physical activity in the development of skeletal mass in children. J Bone Miner Res 6:1227-1233; 1991.

27. Taafe, D. R., Robinson, T. L., Snow, C. M., and Marcus, R. High impact 
exercise promotes bone gain in well trained female athletes. J Bone Miner Res 12:255-260; 1997.

28. Teegarden, D., Proulx, W. R., Kern, M., Sedlock, D., Weaver, C. M., and Johnston, C. C., et al. Previous physical activity relates to bone mineral measures in young women. Med Sci Sports Exerc 28:105-113; 1996.

29. Teegarden, D., Proulx, W. R., Martin, B. R., Zhao, J., McCabe, G. P., and Lyle, R. M., et al. Peak bone mass in young women. J Bone Miner Res 10:711-715; 1995.

30. Valdimarsson, O., Kristinsson, J. O., Stefansson, S. O., Valdimarsson, S., and
Sigurdsson, G. Lean mass and physical activity as predictors of bone mineral density in 16-20 year old women. J Intern Med 245:489-496; 1999.

31. Van Staveren, W. A., de Boer, J. D., and Burema, J. Validity and reproducibility of a dietary history method estimating the usual food intake during one month. Am J Clin Nutr 42:554-559; 1985.

32. Welten, D. C., Kemper, H. C. G., Post, G. B., van Mechelen, W., Twisk, J., and Lips, P., et al. Weight bearing activity during youth is a more important factor for peak bone mass than calcium intake. J Bone Miner Res 9:1089$1096 ; 1994$. 